\title{
Camilo Bautista Ochoa, un santandereano que se enamoró del Pacífico
}

\section{Jesús Glay Mejía-Naranjo}

Trabajador Social. Magíster en Salud Pública

Universidad del Valle. Cali, Colombia

https://orcid.org/0000-0002-5489-1318 • jesgla02@yahoo.es

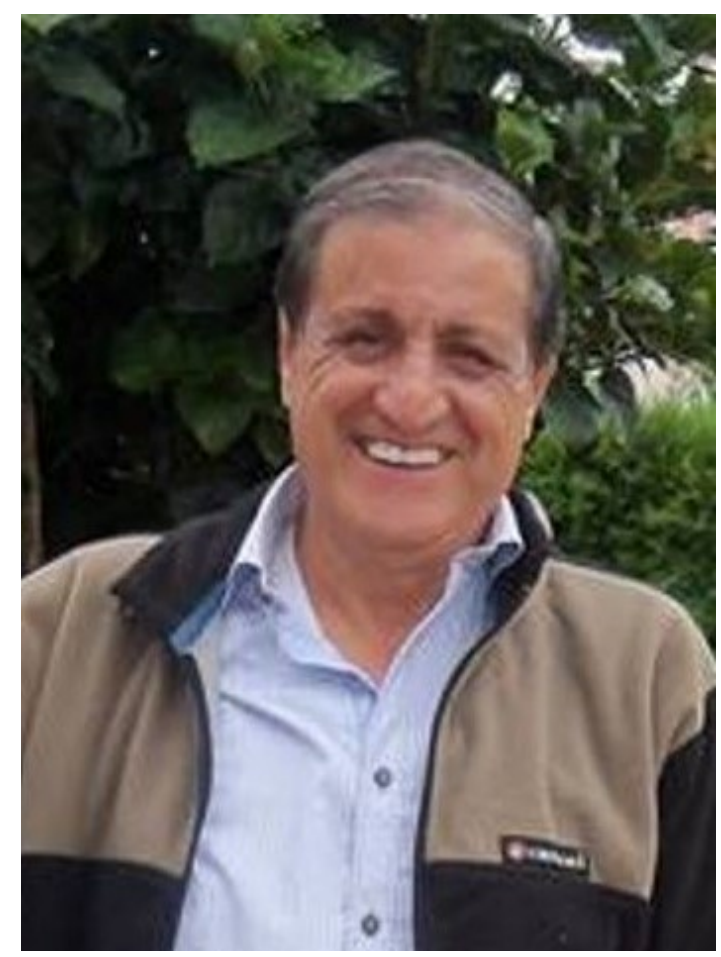

Fuente: Archivo Corpruvalle

De espíritu aventurero, en medio del entusiasmo de su juventud, Camilo se dedicó a trasegar por los senderos que el tiempo y su caminar le abrieron. Primero, se ocupó de explorar nuevos territorios como estudiante en Bogotá en la Universidad Nacional y también en la Universidad Javeriana; luego, ya profesional se dedicó a la docencia en la Universidad Tolima. Junto a sus compañeros de ideología participó en el debate político y la confrontación acerca del sistema educativo, lo que pronto lo obligó a dejar esas 
tierras para llegar en 1973 al Valle del Cauca, región que lo embrujó. Disfrutó de la salsa, de los paisajes, de los ríos, de la brisa marina. En medio de este ambiente del trópico se vinculó a la Facultad de Trabajo Social, hizo suyo este proyecto, acompañó las luchas estudiantiles de los años 70 y participó en el movimiento para alcanzar la incorporación total de la Facultad a la Universidad del Valle.

Por espacio de 25 años estuvo vinculado a la Universidad del Valle, ejercicio la jefatura del Departamento de Trabajo Social por varios períodos, se desempeñó en la dirección del Programa de gerontología, tema que lo apasionó, y pronto se convirtió en gerontólogo sumando otro semblante a su perfil, por cierto, amplio y de alguna manera plástico por aquello de sus posibilidades de cambio.

En 1975, se enamoró de la trabajadora social Francia Elena Pizarro con quien constituyó una familia conformada por dos hijos, Camilo Ernesto y Natalia, arquitecto y abogada respectivamente, grupo familiar que se convierte en su proyecto de vida. Se hizo hombre del Pacífico sin abandonar su talante santandereano, evidente en su temperamento y en la fuerza con que defendía sus ideas en las cuales se reafirmaba hasta hacerlas realidad. Siempre se salía con las suyas, no importaban el tiempo ni las energías que le demandaba convencer a los demás de las bondades de su proyecto. En medio de su 240 talante impulsivo estaba el hombre, el ser humano, el amigo. Siempre tenía un consejo, una recomendación; a su manera, un chiste, una metáfora, un cuento, eran los recursos de Camilo para comunicar sus mensajes.

Con su apasionamiento, dedicó los últimos 32 años de su vida al Club de los profesores de Univalle, proyecto que lo enamoró, y le hizo dejar de lado otras tareas. Este proyecto fue el detonante para darle salida al líder social que llevaba dentro de su Ser, una empresa pensada para los docentes y sus familias; trabajando en equipo con un grupo de profesores pronto alcanzaron su propósito y en diciembre de 1988 inauguraron el Club Piedralinda. Ya lograda la meta, había que plantearse nuevos retos y pronto se las ideó para convencer a los profesores de abrir una sede del Club en la zona de Tocotá, allá en la montaña, por los farallones que miran al Océano Pacífico, allí se construyó una sede campestre. Consolidado el proyecto, siempre con la sensibilidad social que lo caracterizaba, se empeñó en trabajar con la comunidad de Tocotá: impulsó el trabajo con los niños y niñas de la escuela, sabiendo que podía dar algo de sí, lo sentía como una necesidad. Como no era hombre de indiferencias u olvidos, pronto encontró los cómplices para esta nueva tarea, un puñado de profesores, entre ellos su hermano José.

Camilo se convirtió en el símbolo de Club, no había profesor que llegara y no preguntara por Camilo, no había día en que no pasara por las mesas saludando a la familia de los 
profesores, momento que era aprovechado por las familias y Camilo para ponerse al día en la novedades, avances y desarrollos del Club; en medio de la conversación, poner una queja, indagar por algún asunto o recibir una jalada de orejas.

Así trascurrieron 46 años, medio siglo del santandereano que hizo su vida en el Valle dulce del Pacífico, que formó su familia, que hizo de la Universidad su proyecto académico, del Club su compromiso social; esta fue su tesis de grado, la hizo en la práctica, se convirtió en trabajador social, en padre, esposo, amigo e impulsor de nuevas energías y concreciones.

Un día del verano de 2019 se marchó al infinito, el maestro, el apasionado, el amigo. Nos dejó su obra, sus recuerdos, su enseñanza: hay que perseverar hasta hacer realidad los anhelos, que son propósitos para compartir con los demás. 